\title{
CALCULATION OF NEUTRON FLUX DISTRIBUTION AT PIERCING BEAM PORTS OF PLATE TYPE RESEARCH REACTOR BANDUNG
}

\author{
Epung Saepul Bahrum ${ }^{1}$, Prasetyo Basuki ${ }^{1}$, Alan Maulana ${ }^{1}$, Jupiter Sitorus Pane ${ }^{1}$ \\ ${ }^{1}$ Center for Applied Nuclear Science and Technology, National Nuclear Energy Agency - \\ Bandung, Jawa Barat 40132 \\ Email: epung@batan.go.id \\ Diterima : 10-01-2020 \\ Diterima dalam bentuk revisi: 12-05-2020 \\ Disetujui: $12-06-2020$
}

\begin{abstract}
CALCULATION OF NEUTRON FLUX DISTRIBUTION AT PIERCING BEAM PORTS OF PLATE TYPE RESEARCH REACTOR BANDUNG. Based on a strategic plan of TRIGA 2000 Bandung's future operation, BATAN has already decided to implement an option to convert the fuel elements core of TRIGA 2000 from using the cylindrical type of elements produced by General Atomic to MTR plate type of fuel elements produced by local fuel element manufacture. The core design calculation has proved that the core configurations of $5 \times 5$ matrix using local plate type fuel elements met the requirement of core neutronics design. In addition to the current core configuration, further study must be added to consider the use of beam ports as utilization facilities in the design. The neutron flux distribution at piercing beam port has been calculated based monte carlo algorithm using TRIGA MCNP and MCNP software. The calculation result showed that at piercing beam port surface neutron flux distribution is not quite symmetric. The highest neutron flux at piercing beam port is $9.4 \times 10^{8}\left(\mathrm{n} / \mathrm{cm}^{2}\right.$. sec $)$, where as the flux of neutron thermal energy group is $3.54 \times 10^{8}\left(\mathrm{n} / \mathrm{cm}^{2} . \mathrm{sec}\right)$. These results are considerably appropriate for such core configuration and as a result, they can be used as a basic data for designing Plate Type Research Reactor Bandung, especially for neutron diffraction experiment
\end{abstract}

Keywords : TRIGA 2000 reactor, Plate Type Research Reactor Bandung, Plate type fuel element, Neutron flux distribution, TRIGA MCNP, MCNP, Piercing beam port

\section{ABSTRAK}

PERHITUNGAN DISTRIBUSI FLUKS NEUTRON PADA PIERCING BEAM PORT REAKTOR PENELITIAN TIPE PELAT BANDUNG. Berdasarkan rencana strategis jangka panjang Reaktor TRIGA 2000 Bandung, BATAN telah memilih opsi untuk mengubah elemen bahan bakar Reaktor TRIGA 2000 dari tipe silinder yang diproduksi oleh General Atomic ke tipe pelat MTR produksi dalam negeri. Perhitungan desain teras telah membuktikan bahwa konfigurasi teras berbentuk matrik $5 \times 5$ menggunakan elemen bahan bakar jenis pelat produksi dalam negri telah memenuhi persyaratan desain neutronik teras. Selain konfigurasi teras kajian lain harus dilakukan untuk mempertimbangkan penggunaan beam port sebagai fasilitas iradiasi neutron. Distribusi fluks neutron pada piercing beam port telah dihitung menggunakan algoritma monte carlo perangkat lunak MCNP. Hasil perhitungan menunjukkan bahwa pada permukaan piercing beam port distribusi fluks neutron tidak cukup simetris. Fluks neutron tertinggi pada piercing beam port adalah $9,4 \times 10^{8}\left(\mathrm{n} / \mathrm{cm}^{2} . \mathrm{sec}\right)$, sedangkan fluks neutron termal adalah $3,54 \times 10^{8}\left(\mathrm{n} / \mathrm{cm}^{2} . \mathrm{sec}\right)$. Hasil ini menunjukkan bahwa konfigurasi teras tersebut sangat memadai apabila akan dibangun fasilitas difraksi neutron pada Reaktor Penelitian Tipe Pelat Bandung.

Kata Kunci : Reaktor TRIGA 2000, Reaktor Penelitian Tipe Pelat Bandung, Bahan Bakar Tipe Pelat, Distribusi Flux Neutron, TRIGA MCNP, MCNP, Piercing Beam Port 


\section{INTRODUCTION}

TRIGA 2000, a TRIGA MARK II type of General Atomic nuclear research reactor, which is located in Bandung, is one of the three nuclear research reactors of BATAN. The other two BATAN nuclear research reactors are RSG GAS at Serpong and Kartini at Yogyakarta. TRIGA 2000 with nominal power of $2 \mathrm{MW}$ thermal has been operated since 2000. Within fifty-three years of operation, TRIGA 2000 has been successfully up graded two times. First power upgrading was done to increase the power from $250 \mathrm{kw}$ to $1000 \mathrm{kw}$, and the second from $1000 \mathrm{kw}$ to $2000 \mathrm{kw}$.

Due to one of the fuel follower control rods had achieved its burn-up more than $50 \%$, this control rod must be replaced, but there was no reserve control rod available. Then our local engineers tried to design and manufacture the control rod based on our experience in developing RSG-GAS control rods. The design and manufacture of local control rod were successfully tested and now is used as a replacement of the previous control rod.

One of the hot issues in the future operation of TRIGA 2000 was triggered by the fact that General Atomic will not produce TRIGA MARK II type of fuel elements any more since 2011. Of course, this problem will impact the continuations of the TRIGA 2000 operation. In order to preserve the TRIGA 2000 operation, BATAN has performed a strategic plan study on the continuation of TRIGA 2000 operation in the future and one of the options of the result was to replace the TRIGA MARK II cylinder type fuel element of TRIGA 2000 reactor with local plate type fuel elements. This local plate fuel has been successfully produced and equipped at RSGGAS research reactor.

A study on neutronic, thermal hydraulic and safety of TRIGA 2000 plate fuel type or Plate Type Research Reactor Bandung (PTRRB) have been reported. Basuki (1)(2) has studied and designed the core configuration, safety and develop fuel management of PTRRB, however, the study did not consider neutron flux distribution at piercing beam tube yet. The purpose of this study is to simulate neutron flux distribution at piercing beam tube base on Basuki's (1)(2) conceptual design. Data of neutron flux distribution at piercing beam tube is very important for designing neutron diffraction instrument of PTRRB.

Several nuclear reactor research utilization is for neutron diffraction and neutron scattering experiment (3)(4). Recently computer codes have been developed for designing neutron instrument (5) and have been implemented in designing neutron instrument (6). One of the neutron instrument simulation computer code is McStas (5). Based on monte carlo algorithm, McStas computer code could determine optimum configuration of the monochromator, neutron slit, sample position and detector position of the neutron instrument. In simulation process, McStas need several input data such as the distribution of neutron source, shape and dimension of samples and distances of sample detector. Neutron flux distribution calculated by MCNP could be used as McStas neutron source distribution input data (7). Thus, the result of neutron flux distribution at piercing beam port calculated 
by MCNP computer program will be useful data for designing neutron diffraction of PTRRB.

\section{METHODOLOGY}

The model of PTRRB core configuration model is depicted in Figure 1. Figure 1 is generated by TRIGA MCNP computer package. TRIGA is a trade mark of General Atomics and MCNP is a software developed by Los Alamos National Laboratory (8). In Figure 1 reactor core is modeled by square grid, each grid labeled alphabetically A-2, A$3, \mathrm{~A}-4$ etc. Code U3Si2 in each grid is code of U3Si2-Al fuel element and AgInd is control element. Grid number A-2, A-3, A-4, B-1, B3, B-5, C-1, C-2, C-4, C-5, D-1, D-3, D-5, E2, E-3 and E-4 filled by fuel element. Grids number B2, B4, C-3, D-2, and D-4 are reserved for control elements and Grid C-3 planned for central irradiation position. Data of PTRRB listed at Table 1.

The process of neutron flux calculation at piercing beam tube is first using TRIGA MCNP computer code PTRRB reactor core model loaded by fuel element such as Figure 1. TRIGA MCNP computer coded has data base of PTRRB reactor. Data base of PTRRB in TRIGA MCNP computer code reactor core consist of biological shielding, dimensional geometry and material composition of the reactor core and also dimensional, geometry and material composition of neutron beam tube. After reactor core model loaded by fuel element, TRIGA MCNP will generate files correspond to MCNP (Monte Carlo NParticle) software package input file. Initially MCNP will compute effective multiplication factor $\left(k_{e f}\right)$ calculation. $k_{\text {eff }}$ is a base to determine that reactor is in critical condition. In critical condition $\mathrm{k}_{\text {eff }} \approx 1$, it is mean that neutron produced in reactor core is in controlled manner. Some of that neutron will transport to piercing beam tube. Neutron flux at piercing beam port will be calculated related to reactor core fuel configuration.

Table 1. Data of PTRRB (1)

\begin{tabular}{ll}
\hline Reactor thermal power & $2 \mathrm{MWt}$ \\
Reactor core diameter & $53.3 \mathrm{~cm}$ \\
Fuel & U3Si2-Al \\
Enrichment & $20 \%$ \\
Control element & $\mathrm{Ag}-\mathrm{In}-\mathrm{Cd}$ and \\
& U3Si2-Al \\
Number of fuel & 16 \\
element & \\
Number of control rod & 4 \\
Reflector & Beryllium \\
Moderator & $\mathrm{H} 2 \mathrm{O}$ \\
\hline
\end{tabular}

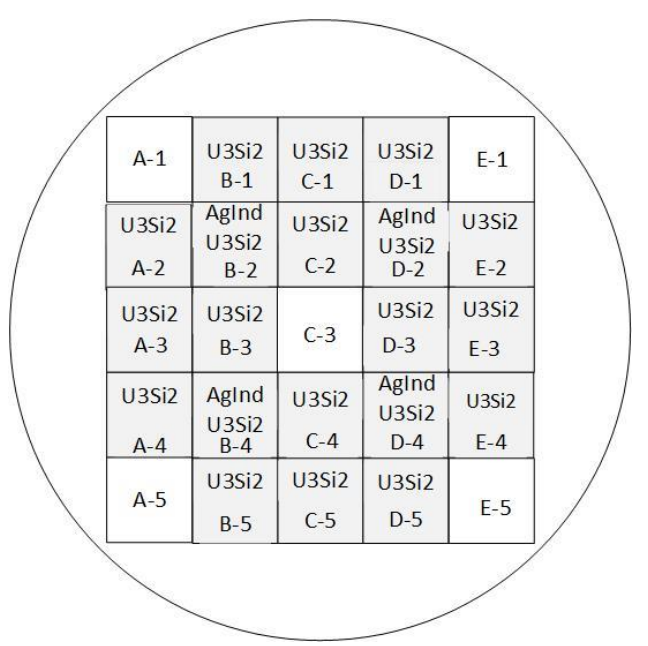

Figure 1. PTRRB core model (1)

Piercing beam port of PTRRB illustrated in Figure 2, 3 and 4. The figures are graphed by VISED (8) software package. To generate Figure 2,3,4 by inputting data of PTRRB to TRIGA MCNP sotware package.TRIGA MCNP software package will create an output 
data for VISED software package for visualizing there dimensional PTRRB reactor. Therefor data visualized by VISED software package is representing the real PTRRB .

Figure 3 is the tip of neutron piercing beam port at xy plane cross section. Figure 3 is required to determine coordinate position at piercing beam port. That coordinate will be used to calculate neutron distribution at piercing beam port. Beside that neutron distribution is very important for neutron diffraction which is carried out at outside of piercing beam port. The coordinate could be specified by reading position of VISED visualization.

In this calculation assumed at xy plane neutron from piercing beam tube passes through only at region marked by point $3,4,7,8$ of Figure 3. Coordinate position of points 1-8 of Figure 3 listed at Table 2. Figure 4 is cross-section of neutron piercing beam port at $x z$ axis. Figure 4 is to illustrate configuration of neutron piercing beam port, neutron piercing beam tube and reactor core. Figures 5 and 6 are expand neutron piercing beam port region at $x z$ axis. In $x z$ plane is assumed that neutron passes through only at region marked by point 10 and 11 of Figure 5 and between point 14 and 15 of Figure 6 . The coordinate position of point 9-12 of Figure 5 are listed in Table 3 and coordinate position of point 13-16 of Figure 6 are listed in Table 4. Base on Figure 3-6 and Table 2-4 the dimension of piercing shutter box and position of piercing beam tube axis at $z$ axis are shown in Figure 7. The dimensional height of piercing shutter is $50.62 \mathrm{~cm}$ and the width is $54.2 \mathrm{~cm}$. The position of piercing beam tube axis is $29.35 \mathrm{~cm}$. This coordinate will be used by FMESH, a MCNP command to generate neutron flux distribution at certain geometry. In this study, geometry of FMESH is cylinder the same shape as piercing neutron beam tube.

Neutron flux calculation at piercing beam port was calculated at condition when fresh fuel element loaded to reactor core and reactor in critical condition. Neutron flux calculation use MCNP 6 software package (8). MCNP is general software package for calculating neutron flux .

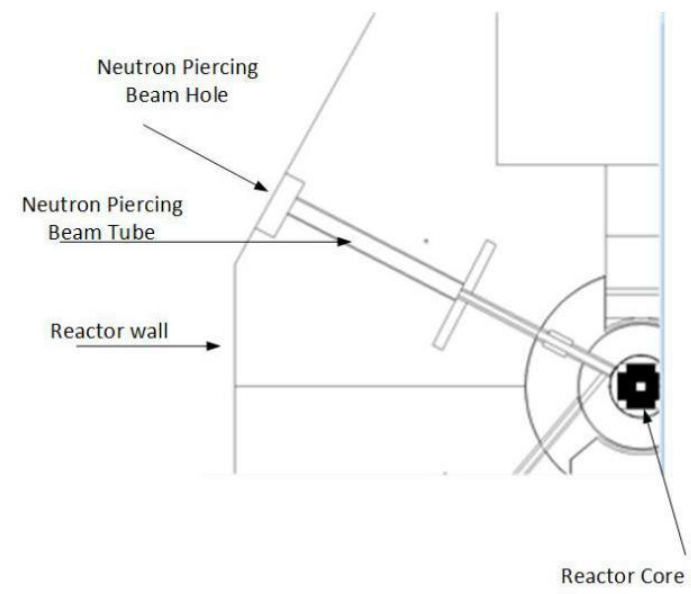

Figure 2. Neutron piercing beam port at xy plane

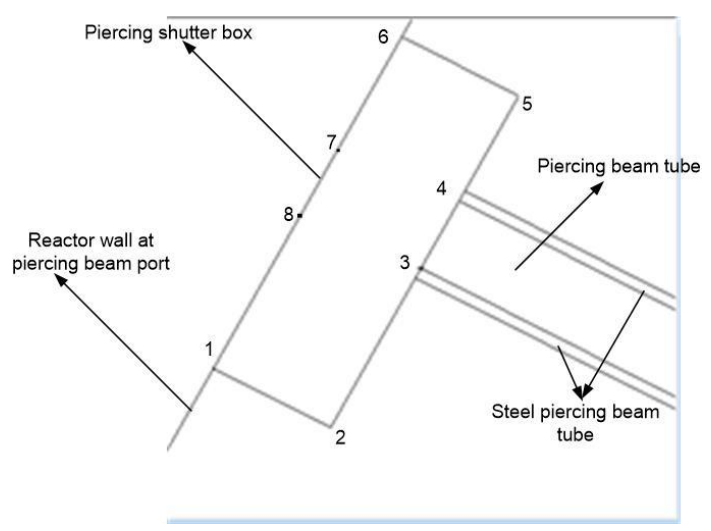

Figure 3. Tip of neutron piercing beam port at $x y$ plane 


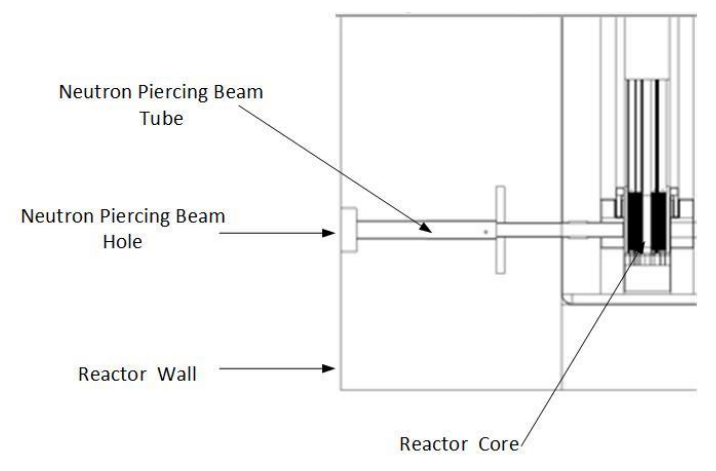

Figure 4. Neutron piercing beam port at xz plane

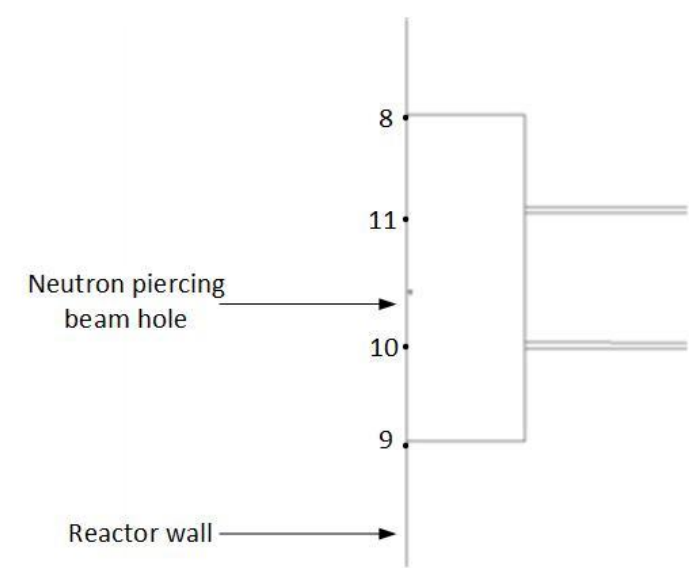

Figure 5. Points at $x z$ plane of piercing beam port. Cross section at $x z$ plane of point 8 at figure 3 .

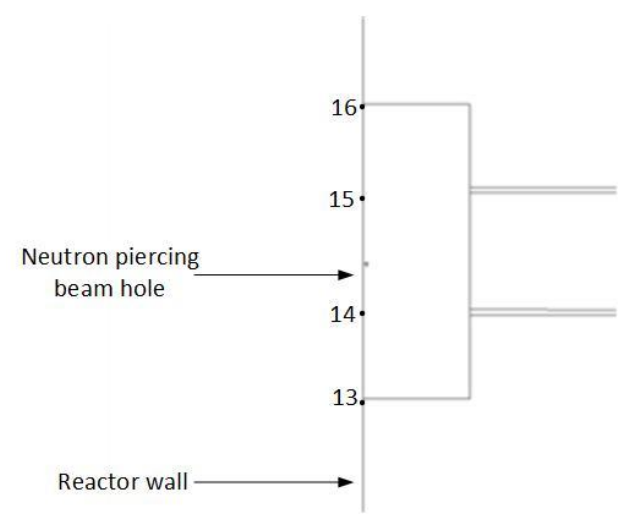

Figure 6. Points at $x z$ plane of piercing beam port Cross section at $x z$ plane of point 7 at figure 3

Table 2. Coordinate of point 1-8 as illustrated at Figure 3

\begin{tabular}{cccc}
\hline Points & $\mathrm{X}$ & $\mathrm{Y}$ & $\mathrm{Z}$ \\
1 & -332.31 & 135.98 & 20.65 \\
2 & -316.21 & 127.99 & 20.65 \\
3 & -303.34 & 150.39 & 20.65 \\
4 & -298.41 & 159.79 & 20.65 \\
5 & -290.16 & 174.83 & 20.65 \\
6 & -306.10 & 183.55 & 20.65 \\
7 & -314.53 & 168.09 & 20.65 \\
8 & -320.20 & 157.91 & 20.65 \\
\hline
\end{tabular}

Table 3. Coordinate of point $9-12$ as illustrated at Figure 5

\begin{tabular}{cccc}
\hline Points & $\mathrm{X}$ & $\mathrm{Y}$ & \multicolumn{1}{c}{$\mathrm{Z}$} \\
9 & -319.65 & 158.94 & 3.68 \\
10 & -319.65 & 158.94 & 19.93 \\
11 & -319.65 & 158.94 & 38.77 \\
12 & -319.65 & 158.94 & 54.31 \\
\hline
\end{tabular}

Table 4. Coordinate of point $13-16$ as illustrated at Fig. 6

\begin{tabular}{cccl}
\hline Points & $\mathrm{X}$ & $\mathrm{Y}$ & \multicolumn{1}{c}{$\mathrm{Z}$} \\
13 & -312.76 & 171.48 & 3.61 \\
14 & -312.76 & 171.48 & 24.35 \\
15 & -312.76 & 171.48 & 34.19 \\
16 & -312.76 & 171.48 & 54.4 \\
\hline
\end{tabular}

Top piercing shutter box

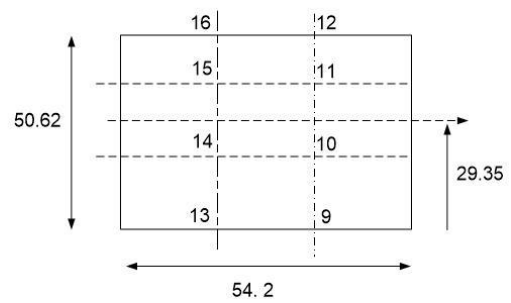

Bottom piercing shutter box

Figure 7. Dimensional of piercing shutter box

\section{RESULT AND DISCUSSION}

First calculation is to calculate multiplication factor $k_{\text {eff. }}$ The calculation result of $k_{\text {eff }}$ is 1.05 , this indicated that reactor is critical. At that condition calculated neutron 
flux distribution for angle $\theta$ and radius $r$ at piercing beam port is displayed at Figure 8 and listed at Table 5. $r=1$ is mean neutron flux distribution around center of piercing beam port and $r=9$ is neutron flux distribution at piercing beam port end side. Plot of neutron flux for $\theta=0-90$ degree is at right side of beam port and $\theta=270-342$ degree is at left side of beam port. Figure 9 and 10 are illustration and relation of FMESH cylindrical geometry model at surface shutter piercing beam port.

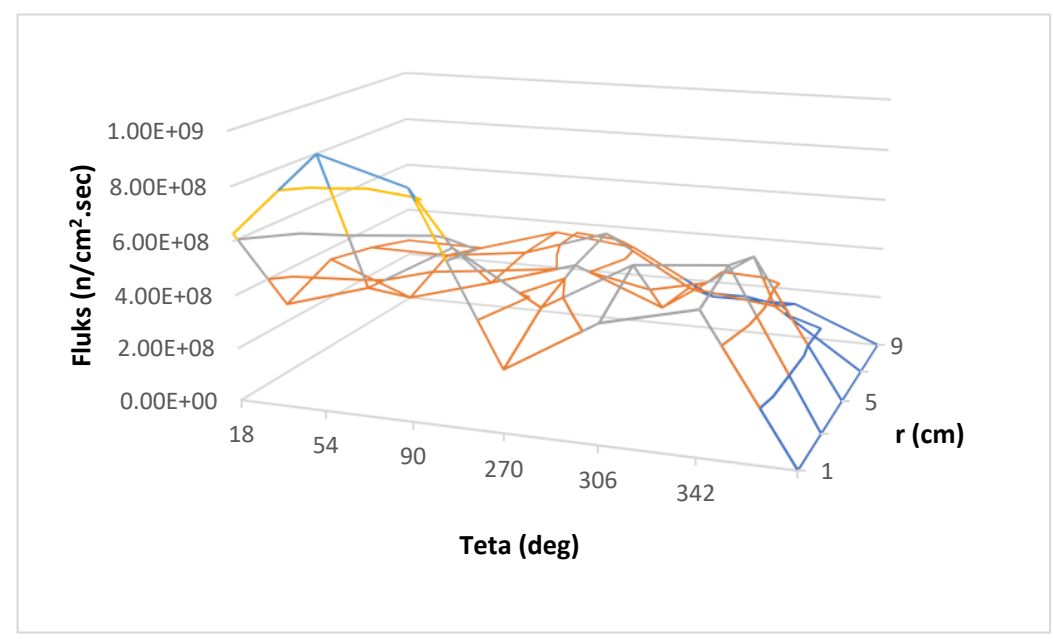

Figure 8. Neutron flux distribution at piercing beam port

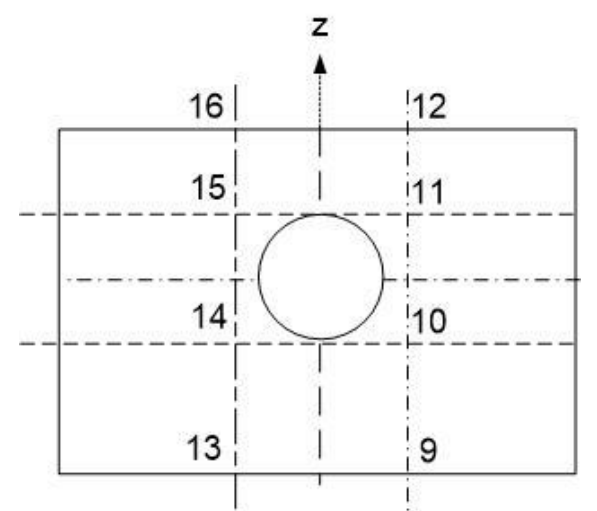

Figure 9. Geometrical of FMESH cylinder at surface of piercing beam port

Table 5. Neutron flux distribution at $r$ and $\theta$

\begin{tabular}{ccccccc}
\hline & \multicolumn{5}{c}{ Neutron Flux $\left(\mathrm{n} / \mathrm{cm}^{2} . \mathrm{sec}\right) \times 10^{8}$} \\
\cline { 3 - 7 } & & \multicolumn{7}{c}{$\mathrm{r} \mathrm{cm}$} \\
\cline { 3 - 7 } & 18 & 6.27 & 2.6 & 3.0 & 3.0 & 9.0 \\
\hline \multirow{2}{*}{ Theta } & 54 & 9.4 & 3.63 & 2.28 & 3.12 & 2.56 \\
$($ deg) & 90 & 8.45 & 5.47 & 3.21 & 3.53 & 3.55 \\
& 270 & 2.32 & 3.54 & 4.22 & 4.61 & 3.16 \\
& 306 & 4.34 & 5.44 & 2.89 & 2.7 & 1.36 \\
& 342 & 5.15 & 5.74 & 5.16 & 2.28 & 1.39 \\
\hline
\end{tabular}


Calculation result is demonstrated at Figure 8. Result of neutron flux calculation is in range $1.36 \times 10^{8} \mathrm{n} / \mathrm{cm}^{2}$. sec. $-9.4 \times 10^{8}$ $\mathrm{n} / \mathrm{cm}^{2} \cdot \mathrm{sec}$. Highest of neutron flux calculation is $9.4 \times 10^{8} \quad \mathrm{n} / \mathrm{cm}^{2}$. sec . Distribution neutron flux at cylindrical surface is not symmetric. More neutron are distributed at angle $18-90$ degree. It is showed that neutron distribute at right side of piercing beam port as displayed by Figure 8 , 9 and 10.

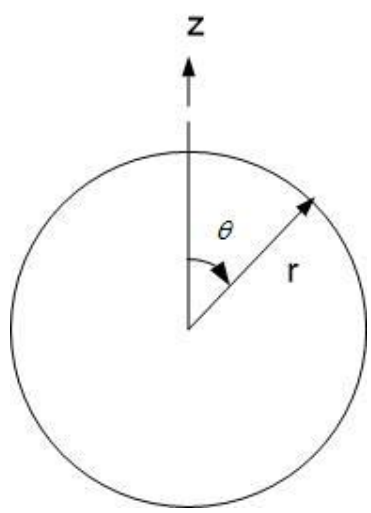

Figure 10. Representation $r$ and $\theta$ of FMESH cylinder

Figure 11 and 12 are presented configuration of neutron piercing beam port and fuel element. At left side of piercing neutron beam port, it is empty grid at reactor core that dedicated for irradiation facility. At right side of neutron piercing beam port all grid is filled by fuel element. Because at right side there is more fuel element than left side so as result of fission reaction more neutron will be produced at right side than left side. This non symmetric fuel element configuration contributes to non symmetric neutron flux at surface neutron piercing beam shutter.

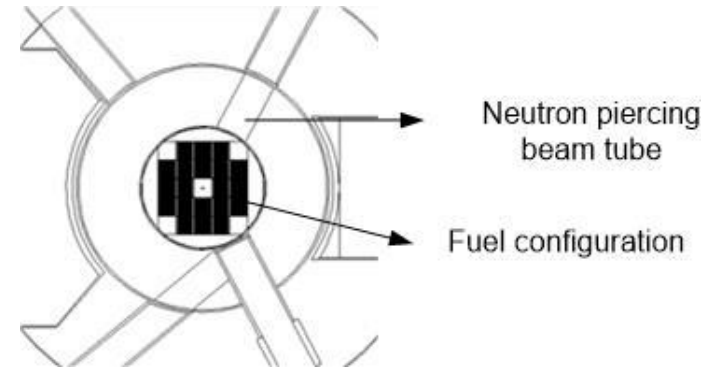

Figure 11. Position piercing neutron beam tube at reactor core

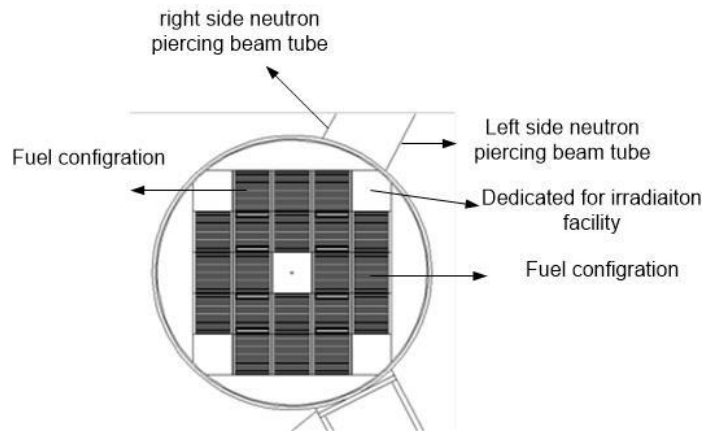

Figure 12. Distribution fuel element near piercing beam port

The result of this calculation could be useful information as a data for designing neutron diffraction instrument of the PTRRB. Design neutron diffraction instrument consist of neuron source from nuclear reactor, monochromator, sample and detector. Based on calculation of this study more neutrons reside at right side so it is necessary to install slit monochromator between piercing beam port and monochromator. Function of slit monochromator to shift neutron ray from right side to center beam line. Further study to be performed is to design optimum distance between piercing beam port to monochromator, length of slit monochromator and distance of monochromatic and sample (6). The optimum 
design to get neutron flux at sample position around $10^{6} \mathrm{n} / \mathrm{cm}^{2} \cdot \sec (9)$. One parameter of neutron diffraction design of PTRRB is neutron flux at simple position is around $10^{6}$ $\mathrm{n} / \mathrm{cm}^{2} . \mathrm{sec}$.

Table 6. Neutron flux for every energy group

\begin{tabular}{cc}
\hline $\begin{array}{c}\text { Neutron Group } \\
\text { Energy }\end{array}$ & $\begin{array}{c}\text { Neutron Flux } \\
\left(\mathrm{n} / \mathrm{cm}^{2} . \mathrm{sec}\right) \times 10^{8}\end{array}$ \\
\hline Thermal & 3.54 \\
Epithermal & 3.38 \\
Fast & 2.85 \\
\hline
\end{tabular}

Table 6 is calculated neutron flux for every energy group at piercing beam port shutter box. Neutron flux of thermal energy group is $3.54 \times 10^{8}\left(\mathrm{n} / \mathrm{cm}^{2} . \mathrm{sec}\right)$ and neutron flux of epithermal energy is $3.38 \times 10^{8}$ $\left(\mathrm{n} / \mathrm{cm}^{2} \cdot \mathrm{sec}\right)$. It seems that neutron flux of thermal energy group and epithermal energy group is slightly different. In neutron diffraction experiment, neutron thermal is used as neutron probe (9) so that condition will impact the performance of neutron diffraction experiments.

\section{CONCLUSION}

Neutron distribution flux at piercing beam port shutter box has been calculated. The result of neutron flux calculation is within a range of $1.36 \times 10^{8} \mathrm{n} / \mathrm{cm}^{2}$. sec. to $9.4 \times$ $10^{8} \mathrm{n} / \mathrm{cm}^{2}$. sec. The highest of neutron flux is of $9.4 \times 10^{8} \mathrm{n} / \mathrm{cm}^{2} . \mathrm{sec}$. However, the distribution of neutron flux at piercing beam port is not quite symmetric. More neutron is distributed at right side of piercing beam port. The neutron flux of the thermal and epithermal energy group is slightly comparable. This will impact to performance when performing neutron diffraction experiment. Further study should be performed to find optimum neutron diffraction instrument configuration of Plate Type Research Reactor Bandung.

\section{ACKNOWLEDGEMENT}

I would like to express my gratitude to PSTNT BATAN who facilitate and finance this research by DIPA and to Mr. Putranto Ilham Yazid who develops TRIGA MCNP software for assistances in using TRIGA MCNP and MCNP software and also to Mr. Ahmad Mudzakir Efendi and Mr. Muhamad Basit Febrian for proofreading the manuscript. Epung Saepul Bahrum is main contributor in this research.

\section{REFERENCES}

1. Basuki P. Desain Neutronika Konversi Elemen Bakar Tipe Pelat Pada Teras Triga 2000 Bandung. ITB; 2013.

2. Prasetyo Basuki, Putranto Ilham Yazid ZS. Desain Neutronika Elemen Bakar Tipe Pelat Pada Teras TRIGA 2000 BANDUNG. J Sains dan Teknol Nukl Indones. 2014;15(2):169-80.

3. Elcombe M. Neutron Scattering at HIFAR-Glimpses of the Past. Quantum Beam Sci. 2017;

4. Li MJ, Liu XL, Liu YT, Tian GF, Gao JB, Yu ZX, et al. The neutron texture diffractometer at the China Advanced Research Reactor. Chinese Phys C. 2016;

5. Nielsen TR, Markvardsen AJ, Willendrup P. McStas and Mantid integration. In: Journal of Neutron Research. 2016.

6. Cussen LD, Lieutenant K. Computer 
simulation tests of optimized neutron

powder diffractometer configurations.

Nucl Instruments Methods Phys Res

Sect A Accel Spectrometers, Detect

Assoc Equip. 2016;

7. Klinkby E, Lauritzen B, Nonbøl E, Kjær

Willendrup $\mathrm{P}$, Filges $\mathrm{U}$, Wohlmuther $\mathrm{M}$,

et al. Interfacing MCNPX and McStas

for simulation of neutron transport. Nucl

Instruments Methods Phys Res Sect A

Accel Spectrometers, Detect Assoc

Equip. 2013;

8. Goorley $\mathrm{T}$, James M, Booth $\mathrm{T}$, Brown

F, Bull J, Cox LJ, et al. Initial MCNP6

release overview. Nuclear Technology.

2012.

9. Gholamzadeh Z, Bavarnegin E, Rachti

ML, Mirvakili SM, Dastjerdi MHC,

Ghods $\mathrm{H}$, et al. Modeling of neutron

diffractometry facility of Tehran

Research Reactor using Vitess 3.3a

and MCNPX codes. Nucl Eng Technol.

2018;

10. Mason TE, Gawne TJ, Nagler SE,

Nestor MB, Carpenter JM. The early

development of neutron diffraction:

Science in the wings of the Manhattan

Project. Acta Crystallogr Sect A Found

Crystallogr. 2013;69(1):37-44. 
-- Blank Page -- 